\title{
Bisphenol A environmental exposure and the detrimental effects on human metabolic health: is it necessary to revise the risk assessment in vulnerable population?
}

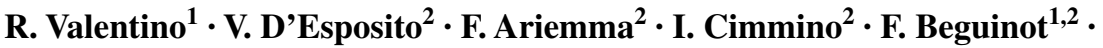 \\ P. Formisano ${ }^{1,2}$
}

Received: 29 April 2015 / Accepted: 9 June 2015 / Published online: 24 June 2015

(C) The Author(s) 2015. This article is published with open access at Springerlink.com

\begin{abstract}
In the last decades, many reports have focused the attention on deleterious effects of novel environmental chemical compounds, including bisphenol A (BPA), on human health. BPA, a common and widely chemical contaminant acting as endocrine disruptor, accumulates in adipose tissue and may affect adipocyte metabolic and inflammatory functions. BPA, at low chronic doses, is now considered as an obesogen compound, and might contribute to the rise of metabolic syndrome, visceral adiposity and diabetes epidemics. The BPA worldwide presence in the environment is responsible for chronic exposure during vulnerable periods, such as foetal and neonatal life. The BPA source of contamination can occur via food, beverage, wastewater, air, dust and soil. BPA, as lipophilic compound, may accumulate into the adipose tissue already during foetal life and may affect adulthood health, through adverse effects on the growth and development of organs and tissues. Thus, based on several studies, it would be crucial to consider further actions aimed to refine risk assessment at least in vulnerable population, such as foetuses, infants and young children, to prevent metabolic diseases and obesity.
\end{abstract}

Keywords Endocrine disruptors - Bisphenol A · Prenatal/ neonatal exposure $\cdot$ Low-grade-inflammation · Obesity · Insulin resistance

R. Valentino

rossvalentino@yahoo.it

1 Institute of Experimental Endocrinology and Oncology (IEOS), National Council of Research (CNR) IEOS-CNR, Federico II University of Naples, via Pansini, 5, 80131 Naples, Italy

2 Department of Translational Medical Sciences, Federico II University of Naples, via Pansini, 5, 80131 Naples, Italy

\section{Introduction}

Recent advances have confirmed the role of chemical environmental pollutants, together with excessive nutrients, in the global obesity epidemic, mainly via adipose tissue dysfunction and inflammation. In particular, these pollutants interfere with several function of endocrine system and so they are called endocrine disrupting chemicals (EDC). Among these compounds, bisphenol A (BPA), primarily used to make polycarbonate plastic and epoxy resins, could represent a causative link between chemical exposure and the "obesogen hypothesis" [1, 2, 4]. BPA is an ubiquitous lipophilic compound with oestrogenic activity and it is able, for example, to migrate from can coatings into foods and beverages during storage, depending on heating process, contact with oil or acetic acid $[1,3]$.

Human BPA exposure is controversially discussed in non-occupational subjects. For its worldwide chronic presence, BPA is detectable in human serum, urine, amniotic fluid, placental tissue and umbilical cord blood $[4,5]$. The total number of epidemiological and toxicological studies in humans are still very small. Several researches, involving in vitro and in vivo models, including humans, wildlife species and laboratory animals, were focused on the mechanistic basis of BPA action in different experimental conditions [1, 3-5]. Current limitations in understanding the global consequences of BPA exposure include incomplete understanding of the cell/tissue specific actions and effects, particularly at different critical windows of susceptibility during the entire life-span [1,3-6].

\section{BPA environmental chronic exposure and biological effects}

A modified synthesis of the most relevant sources of BPA reported in literature has been shown in Table 1, with the 
Table 1 Illustrating the most relevant sources of BPA and its levels in environment, food, beverage, containers and other origins (modified by Kang et al. [5])

\begin{tabular}{lc}
\hline BPA contamination sources & BPA concentration (range) \\
\hline Aquatic environment & $8-21 \mathrm{ng} / \mathrm{ml}$ \\
Air & $2-208 \mathrm{ng} / \mathrm{m}^{3}$ \\
Dust & $0.8-10 \mu \mathrm{g} / \mathrm{g}$ \\
Thermal paper & $54-79 \mu \mathrm{g} / \mathrm{cm}^{2}$ \\
Meats & $17-602 \mathrm{ng} / \mathrm{g}$ \\
Fish & $5-109 \mathrm{ng} / \mathrm{g}$ \\
Vegetables and fruits & $9-76 \mathrm{ng} / \mathrm{g}$ \\
Beverages & $1-18 \mathrm{ng} / \mathrm{g}$ \\
Dairy products & $21-43 \mathrm{ng} / \mathrm{g}$ \\
Infant formula & $0.1-13 \mathrm{ng} / \mathrm{g}$ \\
Cans & $2-82 \mathrm{ppb}$ \\
Plastics & $0.2-26 \mathrm{ppb}$ \\
Dental materials & $0.013-30 \mathrm{mg}$ \\
\hline
\end{tabular}

$p p b$ parts per billion range of concentrations in general environment, including water (river and sea), air and dust [5]. Of interest, BPA human daily intake occurs mostly via foods and beverages, but also via skin exposure after continuously handling thermal paper receipts in occupationally exposed populations such as cashiers, who handle receipts 40 or more hours per week [7].

In humans, BPA chronic exposure, even at nanomolar concentrations, has been reported to be deleterious, mainly involving human reproduction, development, metabolic and inflammatory pathways [1, 2, 4-6]. The number of papers published on PubMed between 1975 and 2015 has been shown in Tables 2 and 3, reporting the main negative effects of BPA, that involve human and animal in vitro and in vivo studies, respectively. Several analyses, including human epidemiological studies, have supported the BPA "obesogen" effects [1, 3-6, 8]. For instance, we have recently reported a significant activation of inflammatory pathways (JNK, STAT3 and NF-kB), with an increased

Table 2 Illustrating in vitro studies showing the main negative effects of BPA, involving different tissue and cell models

\begin{tabular}{|c|c|c|c|}
\hline In vitro studies & Cell models & Negative effects & $\begin{array}{l}\text { Number of published papers } \\
\text { (PubMed 1975-2015) }\end{array}$ \\
\hline Adipose tissue & $\begin{array}{l}\text { 3T3L1 preadipocytes and mature adipocytes } \\
\text { SVF and human adipocytes }\end{array}$ & $\begin{array}{l}\text { Adipocyte differentiation } \\
\text { Insulin signaling } \\
\text { Inflammatory effects }\end{array}$ & 6 \\
\hline Bone tissue & $\begin{array}{l}\text { MC3T3-E1 osteoblastic-like } \\
\text { Reticulocytes }\end{array}$ & $\begin{array}{l}\text { Cell proliferation } \\
\text { Cell differentiation } \\
\mathrm{Ca}^{2+} \text { content }\end{array}$ & 8 \\
\hline Breast cancer & $\begin{array}{l}\text { MCF7 } \\
\text { T47D } \\
\text { BT20 } \\
\text { MDA-MB231 }\end{array}$ & $\begin{array}{l}\text { Cell proliferation } \\
\text { Cell growth } \\
\text { ERE-promoter activation } \\
\text { DNA damage }\end{array}$ & 27 \\
\hline Immune system & $\begin{array}{l}\text { Primary splenocytes (mice) } \\
\text { Primary neutrophil granulocytes }\end{array}$ & $\begin{array}{l}\text { Cytokines production } \\
\text { Reactive species } \\
\text { Intracellular } \mathrm{Ca}^{2+} \\
\text { Th1 and } \mathrm{Th} 2 \text { responses }^{2}\end{array}$ & 91 \\
\hline Liver & НЕР3В & $\begin{array}{l}\text { Hypoxic response } \\
\text { Lipid accumulation }\end{array}$ & 50 \\
\hline Reproductive system & $\begin{array}{l}\text { TTE3 sertoli cells } \\
\text { Spermatogenic cells } \\
\text { LNCaP (prostate) } \\
\text { Granulosa and theca cells }\end{array}$ & $\begin{array}{l}\text { mRNA expression } \\
\text { AR-ER transactivation } \\
\text { AR-ER expression }\end{array}$ & 31 \\
\hline Nervous system & $\begin{array}{l}\text { Primary culture midbrain astrocytes } \\
\text { Neuron/glia }\end{array}$ & $\begin{array}{l}\text { Cell differentiation } \\
\text { GFAP/NeuN immunoreactivity }\end{array}$ & 47 \\
\hline Pancreas & $\begin{array}{l}\text { Primary pancreatic islets } \\
\text { Beta-cells }\end{array}$ & $\begin{array}{l}\text { Insulin release and content } \\
\text { Intracellular } \mathrm{Ca}^{2+} \text { flux } \\
\text { Apoptosis }\end{array}$ & 3 \\
\hline
\end{tabular}

All data were extrapolated from "draft scientific opinion (EFSA panel 2015)" and from PubMed revision from years 1975 to 2015 , reported as number of published papers

$E R E$ oestrogen response element, $A R$-ER androgen receptor-oestrogen receptor, GFAP/NeuN glial fibrillary acidic protein/neuron-specific nuclear protein 
Table 3 Illustrating in vivo studies showing the main negative effects of BPA, involving different models

\begin{tabular}{|c|c|c|c|}
\hline & Methods & Negative effects & $\begin{array}{l}\text { Number of published papers } \\
\text { (PubMed 1975-2015) }\end{array}$ \\
\hline In vivo human studies & $\begin{array}{l}\text { Biomonitoring methods } \\
\text { Correlation studies } \\
\text { Cross-sectional studies } \\
\text { Plasma/urine determinations (ELISA, } \\
\text { GC/MS,HPLC, LC/MS) }\end{array}$ & $\begin{array}{l}\text { General toxicity } \\
\text { Reproduction and development } \\
\text { Neurodevelopment and neuroendocrine } \\
\text { system } \\
\text { Immune system } \\
\text { Cardiovascular system } \\
\text { Metabolism (diabetes, weight gain, obesity) } \\
\text { Genotoxicity } \\
\text { Carcinogenicity }\end{array}$ & 442 \\
\hline $\begin{array}{l}\text { In vivo animal studies } \\
\text { (mice, rats, monkeys) }\end{array}$ & $\begin{array}{l}\text { Prenatal exposure } \\
\text { Neonatal exposure } \\
\text { Adult animals }\end{array}$ & $\begin{array}{l}\text { Immune system } \\
\text { Metabolism (glucose intolerance, } \\
\text { hyper- insulinaemia, diabetes, weight } \\
\text { gain, hyper- tryglyceridemia) } \\
\text { Cancer } \\
\text { Reproduction and development }\end{array}$ & 565 \\
\hline
\end{tabular}

All data were extrapolated from "draft scientific opinion (EFSA panel 2015)" and from PubMed revision from years 1975 to 2015 , reported as number of published papers

secretion of pro-inflammatory cytokines (IL-6 and INF- $\gamma$ ) in human adipocytes, incubated in vitro with $1 \mathrm{nM}$ BPA for $24 \mathrm{~h}$. This pro-inflammatory effect is associated with downregulation of the insulin signalling network and inhibition of insulin-stimulated glucose utilization [9]. Moreover, these results were confirmed in a cross-sectional study on a male population, where a significant correlation was found between BPA plasma levels, inflammation and visceral obesity [8]. In this context, it has been also reported a link between BPA plasma levels, markers of low-grade inflammation and insulin resistance in polycistic ovary syndrome [10], an enigmatic syndrome in which experimental exposure to industrial EDC further deteriorate the hormonal and fertility imbalances [11]. Thus, a putative mechanism by which BPA affects adipocyte metabolic functions and leads to insulin resistance, probably via inflammatory pathways has been hypothesized (Fig. 1).

Besides these well-documented molecular mechanisms on adipose tissue, inflammation and glucose metabolisms, several biological effects have been attributed to low-dose environmental BPA exposure [1, 3-6] (Tables 2, 3 ). Due to its ability to mimic oestrogen activity, BPA can enhance or inhibit the activity of endogenous oestrogens, mainly acting via nuclear oestrogen receptors ER $\alpha$ and $\mathrm{ER} \beta$, but also binding G-protein coupled oestrogen receptor (GPR30). Moreover, BPA could compete with $5 \alpha$-dihydrotestosterone (DHT) for binding at the androgen receptor (AR) causing an anti-androgen effects, leading to male infertility, but also at thyroid hormone receptor (TR), with an interference on TR, affecting the brain morphology and expression of genes related to brain development. Another interesting BPA effect is on pancreatic beta-cells, where BPA can activate receptor-mediated pathways, influencing the rapid influx of calcium and increasing insulin release and glucose metabolism. On the immune system, BPA can affect the immune system functions in humans, involving autoimmunity, adaptative immune response, such as Th1 and Th2 responses, but also elicits differential responses on cytokine production, cell-type and stimulus specific $[1,3-6]$.

\section{BPA and foetal exposure}

The detrimental effects of BPA on tissue and organ development during foetal life are now well documented in literature, mainly in animal models (Table 2). In humans, detectable BPA plasma and urine levels have been reported in several epidemiological studies, with higher values in children and consistent associations with metabolic alterations [1, 3-6]. As consequence of the BPA worldwide presence and to its ability to cross placenta, humans, during the whole life, including foetal and neonatal life, are chronically under BPA low doses exposure. Interestingly, when ingested, BPA is rapidly absorbed mainly at gastrointestinal level and partially inactivated in the liver and intestine via conjugation by uridine $5^{\prime}$-diphospho-glucuronosyltransferase (UDP-UGT) activity [1, 3-6]. Foetal liver has an immature system of detoxifying chemicals, in particular UDP-UGT activity is reduced, and the embryonic/foetal BPA exposure, with subsequently accumulation, may impair the tissue embryonic development and function, particularly affecting adipose tissue functions, insulin sensitivity and fat increase [6, 12]. Moreover, these findings raise the possibility that BPA may alter regulatory genes of the adipogenesis process, at least in part by epigenetic mechanisms. 
Fig. 1 Putative scheme on bisphenol A (BPA) action in adipocyte. BPA can bind oestrogen receptors and/or TLR/ cytokine receptors. BPA may modulate cytokine synthesis by activation of JNK/STAT3/NFkB inflammatory pathway, and by influencing insulin network via IR/AKT down-regulation

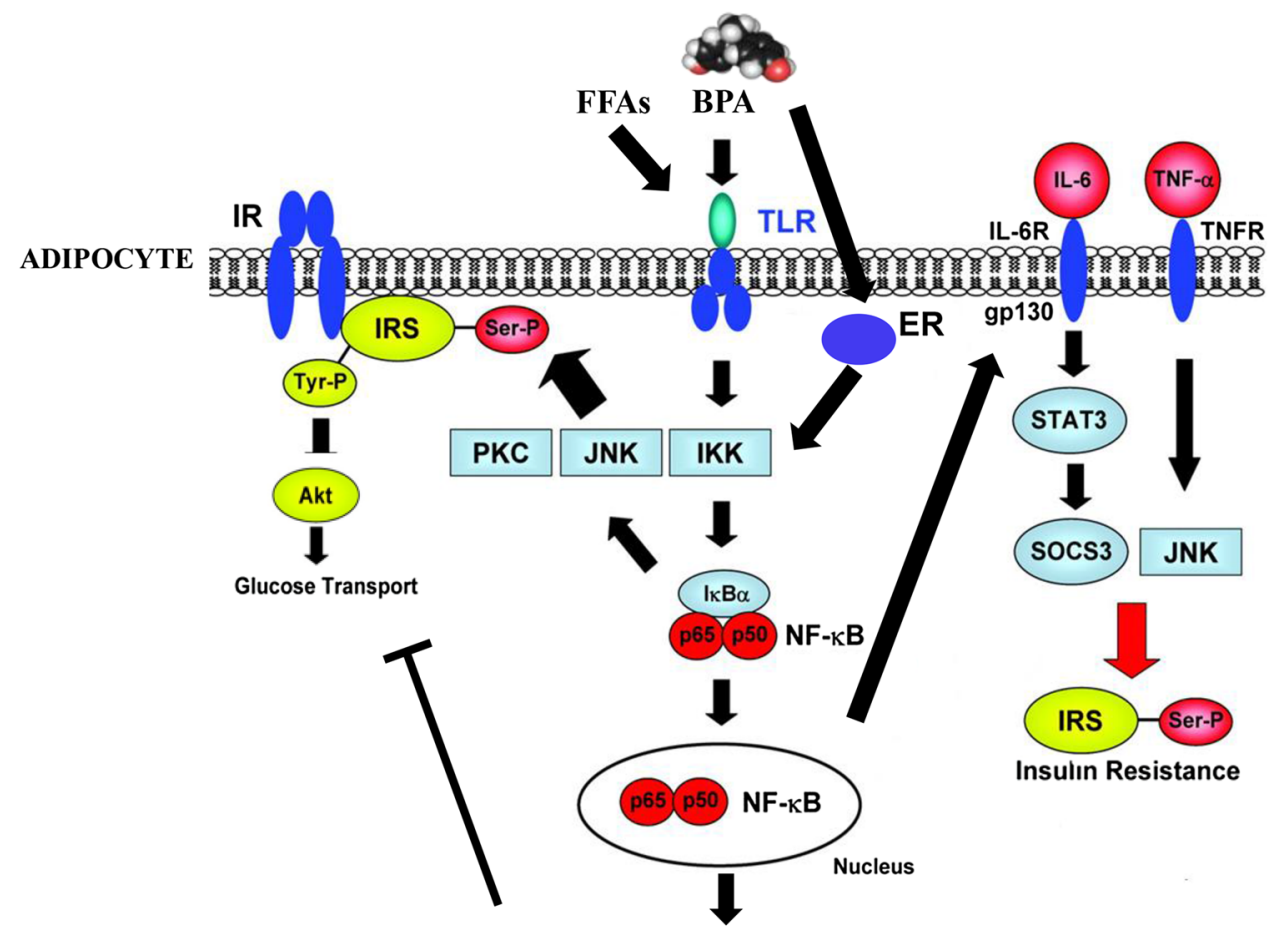

INFLAMMATORY GENE EXPRESSION
It should be noticed that BPA doses, considered "safe" by the European Food Safety Authority (EFSA) [13], may reach "internal" exposure levels higher than those usually required to stimulate molecular endpoints in cultured cells [1, 2, 4-7]. Indeed, BPA at environmental doses may be responsible for reprogramming of the endocrinemetabolic status, with development of systemic low-grade inflammation, insulin resistance and metabolic syndrome during the whole lifespan, particularly when other environmental challenges occur, such as high-fat diet $[1-6,8$, $9,12]$.

Considering the significant difference in BPA pharmacokinetic between animals and humans and in low-dose vs high-dose effects, additional in vivo and in vitro studies involving humans are needed to better define BPA metabolic effects. In particular, BPA deleterious effects should be better defined in vulnerable population, such as foetuses, infants and young children, where also cumulative with mixture of different environmental chemical pollutants may affect the correct tissue development and organogenesis. The embryonic critical window of exposure, can involve systemic metabolic homeostasis and adulthood health programming, in agreement with the new concept of "developmental origins of health and disease", which underlies foetal basis for adult diseases [12].

In other words, BPA foetal/neonatal exposure levels, which may be responsible for increased human health risk, should not be underestimated. Current researches are in progress to sort the effect of foetal programming as a contributing factor in adult metabolic diseases, particularly in obesity, insulin resistance, metabolic syndrome and diabetic epidemics $[6,12]$.

Thus, although all of these hypotheses need thorough examination, caution should be given by National and International Regulatory Agencies, on the potential deleterious role of BPA [14] but also of BPA-like compounds (such as bisphenol $\mathrm{F}$ and bisphenol S), which are gradually replacing BPA in industrial applications [15].

\section{Conclusions}

In humans, the continuous BPA chronic exposure from canned goods, drinking plastic packaging and thermal paper must be reduced. To avoid the contact between plastic containers and food and beverage, particularly during foetal/neonatal life, must be the future goal, for example by privileging fresh foods. Interestingly, France has recently abolished BPA from all packaging food, to reduce drastically the BPA intake. Safety guidelines should give more attention to the potential consequence in vulnerable people worldwide, also considering that the BPA environmental exposure is modifiable through behavioural changes. A reduction of BPA exposure can represent an attractive target for prevention of diseases which represent a serious problem of global proportion and economic and social emergencies, such as obesity, metabolic syndrome and diabetes. 
Conflict of interest The authors have nothing to declare and no competing interests. All authors have read and approved the final manuscript.

Ethical approval This article does not contain any studies with human participants or animals performed by any of the authors.

Informed consent For this type of study formal consent is not required.

Open Access This article is distributed under the terms of the Creative Commons Attribution 4.0 International License (http://creativecommons.org/licenses/by/4.0/), which permits unrestricted use, distribution, and reproduction in any medium, provided you give appropriate credit to the original author(s) and the source, provide a link to the Creative Commons license, and indicate if changes were made.

\section{References}

1. Pereira-Fernandes A, Demaegdt H, Vandermeiren K, Hectors TL, Jorens PG, Blust R, Vanparys C (2013) Evaluation of a screening system for obesogenic compounds: screening of endocrine disrupting compounds and evaluation of the PPAR dependency of the effect. PLoS One. doi:10.1371/journal.pone.0077481

2. Vandenberg LN, Hauser R, Marcus M, Olea N, Welshons WV (2007) Human exposure to bisphenol A (BPA). Reprod Toxicol 24(2):139-177

3. Wetherill YB, Akingbemi BT, Kanno J, McLachlan JA, Nadal A, Sonnenschein C, Watson CS, Zoeller RT, Belcher SM (2007) In vitro molecular mechanisms of bisphenol A action. Reprod Toxicol 24(2):178-198

4. Rochester JR (2013) Bisphenol A and human health: a review of the literature. Reprod Toxicol 42:132-155. doi:10.1016/j. reprotox.2013.08.008

5. Kang JH, Kondo F, Katayama Y (2006) Human exposure to bisphenol A. Toxicology 226(2-3):79-89

6. Liu J, Yu P, Qian W, Li Y, Zhao J, Huan F, Wang J, Xiao H (2013) Perinatal bisphenol A exposure and adult glucose homeostasis: identifying critical windows of exposure. PLoS One 8(5):e64143. doi:10.1371/journal.pone.0064143
7. Ehrlich S, Calafat AM, Humblet O, Smith T, Hauser R (2014) Handling of thermal receipts as a source of exposure to bisphenol A. JAMA 311(8):60-859. doi:10.1001/jama.2013.283735

8. Savastano S, Tarantino G, D'Esposito V, Passaretti F, Cabaro S, Liotti A, Liguoro D, Perruolo G, Ariemma F, Finelli C, Beguinot F, Formisano P, Valentino R (2015) Bisphenol-A plasma levels are related to inflammatory markers, visceral obesity and insulinresistance: a cross-sectional study on adult male population. $\mathrm{J}$ Transl Med 13:169. doi:10.1186/s12967-015-0532-y

9. Valentino R, D'Esposito V, Passaretti F, Liotti A, Cabaro S, Longo M, Perruolo G, Oriente F, Beguinot F, Formisano P (2013) Bisphenol-A impairs insulin action and up-regulates inflammatory pathways in human subcutaneous adipocytes and 3T3-L1 cells. PLoS One. doi:10.1371/journal.pone.0082099

10. Tarantino G, Valentino R, Di Somma C, D'Esposito V, Passaretti F, Pizza G, Brancato G, Orio V, Formisano P, Colao A, Savastano $\mathrm{S}$ (2013) Bisphenol A in polycystic ovary syndrome and its association with liver-spleen axis. Clin Endocrinol 78:447-453

11. Palioura E, Diamanti-Kandarakis E (2013) Industrial endocrine disruptors and polycystic ovary syndrome. J Endocrinol Invest 36(11):1105-1111

12. Alonso-Magdalena P, García-Arévalo M, Quesada I, Nadal Á (2015) Bisphenol-a treatment during pregnancy in mice: a new window of susceptibility for the development of diabetes in mothers later in life. Endocrinology 156(5):1659-1670. doi:10.1210/en.2014-1952

13. European Food Safety Authority (EFSA) (2015) Report on the two-phase public consultation on the draft EFSA scientific opinion on bisphenol A (BPA). EFSA supporting publication EN-740

14. Myers JP, Vom Saal FS, Akingbemi BT, Arizono K, Belcher S, Colborn T, Chahoud I, Crain DA, Farabollini F, Guillette LJ Jr, Hassold T, Ho SM, Hunt PA, Iguchi T, Jobling S, Kanno J, Laufer H, Marcus M, McLachlan JA, Nadal A, Oehlmann J, Olea N, Palanza P, Parmigiani S, Rubin BS, Schoenfelder G, Sonnenschein C, Soto AM, Talsness CE, Taylor JA, Vandenberg LN, Vandenbergh JG, Vogel S, Watson CS, Welshons WV, Zoeller RT (2009) Why public health agencies cannot depend on good laboratory practices as a criterion for selecting data: the case of bisphenol A. Environ Health Perspect 117(3):309-315. doi:10.1289/ehp.0800173

15. Rochester JR, Bolden AL (2015) Bisphenol S and F: a systematic review and comparison of the hormonal activity of bisphenol A substitutes. Environ Health Perspect. doi:10.1289/ehp.1408989 